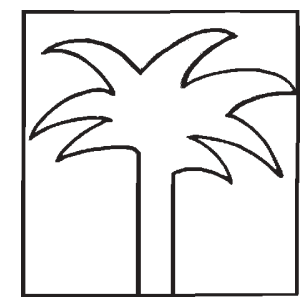

\title{
Replicating Grameen in Papua New Guinea
}

\author{
Rebecca Fleischer
}

The Lik Lik Dinau Abitore Trust (LLDAT) is a micro-credit and savings project which has been operating in Papua New Guinea since 1994, replicating the approach of the Grameen Bank in Bangladesh. Here, the issues and constraints presented to the Grameen model by the PNG environment are examined, using the LLDAT as a case study. Major issues which impact on the project include geographic isolation, linguistic diversity, a high level of violence, and local cultural and economic issues. Problems encountered include relatively low repayment rates (by Grameen Bank standards), difficulties in enforcing loan conditions, and a slow pace of project implementation. But the project has also experienced numerous successes, and is working towards improving its adaptation of the model.
Rebecca Fleischer has worked with AusAID in Papua New Guinea and in Canberra and currently works with International Development Support Services (IDSS) in Melbourne.
Papua New Guinea is a country with relatively low levels of social and economic development, particularly for women. Severe social problems, including unemployment, lawlessness and domestic violence, combine with a particular set of geographic, historical, cultural and economic conditions to make life difficult for the country's rural poor, and especially so for the women. Selfhelp through small-scale credit and savings facilities for income-generating activities is a relatively new concept in Papua New Guinea, although some forms of rural credit have existed since the 1960s. The need for such credit and savings appears high.
The Lik Lik Dinau Abitore Trust (LLDAT) Micro-Credit and Savings Scheme incorporates the principles of the Grameen Bank in Bangladesh, to bring a somewhat new approach in small-scale rural credit and savings to Papua New Guinea. Specific characteristics of the approach include strict targeting of loans to the poorest sectors of the community, a closely monitored, highly disciplined approach to credit, and linking savings to credit. Although the scheme has encountered numerous difficulties and constraints, it has been successful in a number of ways. 


\section{Background}

Poverty remains widespread in Papua New Guinea, and the need for improvement in basic traditional diets and standard of living is high. This is particularly so in remote and isolated areas, which are characterised by poor infrastructure and lack of access to basic social services. Papua New Guinea continues to receive large amounts of foreign aid (including $\mathrm{A} \$ 300$ million a year from the Australian Government), but the benefits of this aid (bilateral government aid in particular) are slow to filter through to the under-privileged rural population.

Women play a key role in the social and economic system of Papua New Guinea; for example women currently produce and process over 80 per cent of the country's food (Papua New Guinea 1995a). However, women generally experience a lower standard of living than men, and have poorer access to education, health services, employment, information and resources, and represent-ation in the public and private sectors. Furthermore women and children in Papua New Guinea suffer from high rates of alcohol-related domestic violence and sexual assault (UNDP 1993:2). A number of women's organisations have developed since independence and have been active at the international lobbying and policy levels (including the Women's Division of the Department of Religion, Home Affairs and Youth and the National Council of Women). But achievements have been minimal in terms of improving the day-to-day situation of most Papua New Guinean women.

\section{The need for small-scale credit and savings in Papua New Guinea}

Despite the continuing prominence of the traditional way of life in Papua New Guinea, the cash economy is growing.
People have an increasing need for money to pay taxes, health costs and school fees for their children, and to buy goods such as rice, tinned fish, second-hand clothes, beer and tobacco. This demand for cash and the limited opportunities available to earn it creates obvious frustrations, and exacerbates social problems. The need for methods of income generation is high, particularly in the rural areas, and particularly for women.

The numbers of village women in Papua New Guinea entering the cash economy through income-generating activities has been growing in recent years, creating an expanding informal sector. While women are able to use existing skills to enter the informal sector, they often lack the resources to kick-start such activities. Women wishing to gain access to credit to start microenterprises are faced with many barriers, including very high transaction costs for banking services (which include both bank fees and the costs of accessing bank services, such as transport costs, lost time from work and so on), and the need for significant collateral to obtain even very small loans.

The provision of small-scale credit and savings facilities for rural women is about removing these barriers. In some developing countries small-scale credit has proven to be a highly effective means of self help for women who want to increase their income, enabling them to create income-generating activities through self employment, and to save some of that income to improve their situation. Self employment is particularly suitable for poor rural women, as it allows them the flexibility to meet other obligations (including child minding and producing food), as well as broadening their opportunities, increasing their status, and providing them with a focus to work together with other women. Benefits gained by the women usually flow on to the rest of the family. Provision of smallscale rural credit and savings to women is 
one method of attempting to address the major social and economic problems of Papua New Guinea at their roots. It also addresses an area neglected by most large government and foreign aid-funded development projects, that is, improving the lives of poor rural people (particularly women) by assisting and encouraging them to develop their own income-earning activities.

This demand for small-scale rural credit and savings schemes is coming from the women of Papua New Guinea themselves. At the 4th UN Conference on Women in Beijing in 1995 the Papua New Guinea delegation presented a National Platform of Action for Women, which called for the economic empowerment of women, and recommended that credit schemes for women be strengthened and expanded (Papua New Guinea 1995b). Research also indicates that there is a strong demand for credit for income generating activities among women and women's groups in rural areas, for example, as revealed by the ILO/ UNDP Employment Strategy and Human Resource Development mission, which held extensive discussions with women throughout the country (UNDP 1993:5).

\section{Existing sources of small-scale rural credit and savings}

\section{Informal}

Papua New Guinea has a number of informal savings and credit arrangements, most of which are based to some degree on traditions and customs. The most common of these is transactions of money, goods and labour among wantoks. Other sources of informal credit and savings include the following.

- Wok Meri (working women) groups conducting savings and inter-group loans independent of any formal banking system. These groups have strict guidelines (for example, no interest is charged) and ritualised practices (Sexton in Fernando 1991:12). Very little information is available on the current status of the Wok Meri movement, and it does not appear to have been researched in connection with the LLDAT scheme, even though the two schemes have some similar characteristics.

- Rotating Credit and Savings Associations (ROSCAs), found largely among low-income blue-collar workers. Again, there is very little information available about ROSCAs.

- semi-professional moneylenders, who lend small amounts of money short-term to people who are well known to them (mainly among urban blue-collar workers). Conditions on loans include very high interest rates and a specified repayment period.

- Trade store owners (often in the form of consumption credit).

- Hoarding, the simplest form of savings, is common practice among rural women who wish to keep their money away from wasteful husbands (Fernando 1991).

The number of these informal schemes indicates that there is a demand among lower-income rural households for credit of some form.

\section{Formal}

The formal financial institutions of Papua New Guinea are not equipped to service the rural poor. Branches of banks, credit institutions and savings and loan societies are largely confined to the capital city and a few regional centres (Fernando 1991:1). Formal financing systems also impose rules and regulations which the poor are unable to meet, including high transaction costs, minimum balances and collateral requirements.

The only formal financial institution set up to assist the rural poor is the Rural Development Bank of Papua New Guinea. 
The Rural Development Bank was set up specifically to assist agricultural and other rural enterprises, and was expected to play a major role in small-scale lending to the rural sector. However, to date, most loans have been to larger farm units and urban initiatives, and achievements in terms of reaching the rural poor have been disappointing. The Bank does have a miniloans scheme for women and youth (set up in 1994) which provides a limited pool of small loans at low interest rates and without collateral. However conditions for this scheme include that transactions must be done at Rural Development Bank Branches, and certification and fees are required to access loans. As elsewhere, the formal financial system has not found a way to deal successfully with the high costs of servicing small loans and the lack of collateral among the rural poor (ILO in UNDP 1993:9).

\section{Other small-scale rural credit schemes for women}

A number of specifically-targeted women's credit schemes have existed in Papua New Guinea since the 1980s, largely instigated by the Women's Division of the Department of Religion, Home Affairs and Youth, and the National Council of Women. The first of these, the Government Women's Grant Scheme (started in 1982), was a total failure due to lack of awareness regarding usage of credit and lack of monitoring and followup. More recent schemes have had a little more success. The Department of Religion, Home Affairs and Youth piloted a National Women's Credit Scheme in two provinces in the mid-1980s, and expanded to several other provinces during the late 1980s and early 1990s. At least four of these schemes are still operating, and some include Grameen-type characteristics, including loan groups, compulsory savings, and preparation of participants and communities prior to commencing the program.
Problems and criticisms of the National Women's Credit Scheme include the following: repayment rates are relatively low (between 20-70 per cent; New Zealand 1993; Kalap and Tambagle 1996); monitoring is often poor; applicants are not meanstested (such that the poorest women are not targeted); corruption has been reported in some schemes; and there is little emphasis placed on savings through the scheme. The low repayment rates and lack of emphasis on savings have severely hampered the sustainability of the scheme.

However the National Women's Credit Scheme is largely locally initiated and run -an achievement in itself, given that small-scale rural credit for women is still at the experimental stage in Papua New Guinea. Ownership and control of projects is an important issue in terms of the empowerment of Papua New Guinean women, and the National Women's Credit Scheme is certainly a success in that regard. The scheme has recently received funding from both the New Zealand and Papua New Guinea governments to allow it to expand its activities.

A further local initiative worth mentioning is a small indigenous nongovernment organisation called Business Enterprise Support Team (BEST Inc.), which runs small business and community development training for women. BEST is currently trying to establish a revolving credit scheme for groups which complete small business training.

\section{The Grameen Bank and its replications}

The world's most widely-known microcredit model is the Grameen Bank. The Grameen Bank approach was developed in Bangladesh in the late 1970s by Professor Mohamud Yunus. It began as a modest local initiative but has grown into a fully- 
fledged bank with an international reputation based on its successful programs in small-scale lending to the poorest of the poor.

A fundamental principle of the Grameen Bank approach is that it assists poor people to make efforts to break out of poverty, rather than making them dependent on welfare. The Bank works hard to dispel the numerous myths which abound about the poor-that they have no training, no skills, they cannot save, they cannot work together, they have a narrow view of life, they are uninterested in change and so on. The Grameen Bank shows that the poor have in fact only survived because they have these skills and furthermore, given the resources to utilise their skills fully, the poor can and will raise themselves out of poverty.

The Grameen Bank believes that the poor do not make themselves poor through laziness or any other defect, rather 'existing socio-economic and political power structures...puts up a strong shield around the poor (such) that it is nearly impossible (for them) to pierce through it' (UNDP 1993:34). The Grameen Bank attempts to break down these barriers, which include the lack of access to resources in general, and to credit in particular. Barriers to credit for the poor include the requirement for collateral, high transaction fees for small loans, literacy requirements, and barriers to savings (very small savings amounts, lack of access to banks and so on). Access to credit alone is not the answer; the Grameen Bank believes that credit combined with savings is the true key to empowering the poor to raise themselves above the poverty line.

Key operational elements of the Grameen Bank approach to small-scale lending to the poor include

- rigorous targeting of loans to the very poor through an unambiguous land asset and income test
- emphasis on lending to women (95 per cent of members are women), who have proven themselves to be better at repaying loans than men

- group structure for lending (individual loans but group responsibility for repayments)

- no collateral or guarantor requirements; group support and peer pressure substitute for collateral

- simple, open and accountable loan and savings procedures conducted regularly at the village level

- close monitoring of loan repayments and loan utilisation

- loanees use existing skills to build up income-generating activities-support services in the form of training, marketing and extension are kept to a minimum

- compulsory savings requirements

- long-term financial sustainabilityremoving dependence on aid and handouts is a major part of the Grameen Bank's philosophy (this depends on the maintenance of a high recovery rate; the Bank prides itself on its high recovery rate, which remains at about 98 per cent).

The Grameen Bank has now been replicated in over 34 countries around the world. As not all of these replications have been successful, there has been considerable debate about the transferability of the Grameen Bank model. However consensus (and experience) now indicate that the model is transferable to other countries, as long as it is slowly and carefully adapted to differing environments (Grameen Trust 1995:16).

The most important consideration in replicating the Grameen Bank approach in differing environments is that the principles remain the same, although the procedures may change. Overall, the loan repayment rate is a particularly important indicator of a successful Grameen Bank replication 
(although not the only one). Other important principles which need to be closely followed include targeting of the poorest households, group lending structure, simple procedures, village level banking and very close monitoring of loans (Grameen Trust 1995:14).

\section{The Lik Lik Dinau Abitore Trust}

\section{The Lik Lik Dinau (literally, small debts)} Abitore Trust (LLDAT) Micro-Credit and Savings Scheme is the first credit scheme following the Grameen Bank approach to be tried in Papua New Guinea, and as such it is a somewhat risky endeavour. It is significantly different from other microcredit schemes that have operated in Papua New Guinea, in that it targets the poorest members of the community. The aim of the scheme is to deliver micro-credit to disadvantaged women in rural areas and urban settlements, and mobilise savings for improving subsistence living standards through the provision of credit for incomegenerating activities (UNDP 1993). The project was designed by the United Nations Development Programme and the Government of Papua New Guinea in 1993, and started in August 1994.

The Lik Lik Dinau Abitore Trust is a non-profit non-political organisation which was set up specifically to implement the Papua New Guinea Micro-Credit and Savings Scheme. The Scheme is supervised by a Board of Trustees (seven members from various government and non-government organisations), and managed by a United Nations Volunteer who supervises a number of local 'trust assistants'. The project was originally designed in two phases; a pilot phase (1993-95) and an expansion phase (1996 onwards), with an overall timeframe of 12 years. The project was designed to expand very quickly; aiming to open a total of 12 Provincial Branches, gain 5000 members, and disburse loans to a total of $\mathrm{K} 1,400,000$ over the life of the project (UNDP 1993).

The combined Project Head Office and first Branch was opened in Goroka (Eastern Highlands Province) in August 1994. The Eastern Highlands Province was identified as having the most favourable conditions for commencement of the project, including active and cooperative women's groups, villages accessible by roads, markets accessible to villagers, and a supportive Provincial Government. To date the scheme still operates only from Goroka, as expansion plans have not yet been put into practice (although preliminary work has been done for another branch in the Eastern Highlands Province and the other provinces). Experience has shown that the successful establishment and operation of the project takes significantly longer than was originally thought, and the project has simply not generated the resources to expand. Establishment of the first project area is the most difficult; expansion should (at least in theory) become progressively easier.

Financial inputs to the project to date total US\$610,000 from a number of sources, including UNDP, Papua New Guinea Department of Village Services, the Foundation for Law, Order and Justice (a non-government member of the Trust) and a recent grant from the Australian Agency for International Development. Financial inputs may seem large for the achievements of the project to date, but long-term financial and institutional self-sustainability is a major aim of the project-the original project design hoped to achieve this in 5 years, however it is now estimated that 10 years is a more realistic objective.

Key operational features of the LLDAT scheme closely follow those outlined for the Grameen Bank above. There are a few defining features, including an exclusive 
focus on women. This was considered important in minimising risk for the scheme, as in Papua New Guinea men tend to dominate the family and can be particularly uncooperative in some situations (as a generalisation). Another feature worth mentioning is that extensive preparatory work is conducted prior to commencement of the project, which includes information gathering, motivational work, and gaining community support. Detailed operational features of the scheme are outlined in Appendix 1.

\section{LLDAT—strengths and weaknesses}

The achievements of the scheme to date indicate a number of strengths, as well as numerous weaknesses. The project has not yet been fully evaluated (this is planned for late 1996/early 1997). Information on progress has been collected from personal observation, interviews with staff and participants, and progress reports.

\section{Overall indicators of progress}

- The scheme has a total of 312 members (Figure 1).

- The scheme has disbursed 311 project loans. First-round loan disbursements total K64,248, and second-round loan disbursements (which commenced in March 1996) total K10,918 (Figure 2).

- The recovery rate stands at 92 per cent. A recovery rate of 100 per cent was maintained for the first 7 months of the scheme, but it has dropped away gradually since then. Commencement of secondround loans has not altered the recovery rate (Figure 2).

- Savings in the various funds add up to a total of K20,681 (Figure 3). Group Fund and Personal Savings have both grown very quickly (Personal Savings were only introduced in March 1995).
- The original expansion plan has not been met as, in retrospect, it contained highly unrealistic goals. However a revised expansion plan has been adopted, including establishing several sub-branches in the Eastern Highlands Province. Preparatory work and staff recruitment is underway to proceed with these plans.

\section{Strengths and achievements of the scheme}

The LLDAT scheme is progressing well in some aspects. Maintenance of a relatively high repayment rate (over 90 per cent) is a notable achievement, particularly in a country with so many built-in barriers to the Grameen Bank approach (see below). The additional funds provided by AusAID will allow more time for the scheme to adjust to the problems experienced to date. Progress in savings has also been rapid and continues to improve.

As the original goals for expansion have not been met, the Trust has decided that it is better to move slowly than to rush things. Papua New Guinea has a strong Pacific culture which favours a slow and easy approach. However, numerous Grameen Bank replication projects in Asia have failed by trying to move too quickly. The Trust has recognised and adapted to these conditions.

The scheme has managed to reach a significant number of participants in a short period of time (given that the operating area is relatively small). This indicates that levels of need and enthusiasm for the scheme are high. LLDAT has also managed to gain a high level of support from some sectors of the community, including the Provincial Government (which provides office space and pays office-related bills) and numerous village and community leaders. Many of the men in project areas (particularly those who benefit directly from the scheme through their wives) are also highly supportive. 
The scheme started to distribute secondround loans in March 1996, indicating that some of the first-round loans and projects have succeeded (this is a condition of second-round loans). The first group to receive second-round loans provides a good example of highly successful loan utilisation: the members of this group have sufficiently improved their skills to enable them to engage in several seasonal businesses over the year in order to maximise income (for example, a combination of coffee growing, raising chickens, sewing, baking and gardening). These women represent good models for the LLDAT scheme-100 per cent attendance at meetings, regular loan repayments, successful projects, improving lifestyle of families and high levels of support from husbands. It is hoped that the incentive of second-round loans will encourage members still in the first round to continue and progress.

The scheme has provided many benefits to the disadvantaged women who have participated to date. The direct benefits of participating in loans and savings activities include skills and experience in simple financial management, savings discipline, working in a group, and other general skills (such as communication) learnt during the training period. Indirect benefits include empowerment through group formation dynamics, education in self-help principles, enhanced status when enterprises are successful, and increased awareness of social issues through participation in meetings and discussions.

Finally, one of the most important achievements of the scheme is that, as the first close replication of the Grameen Bank in Papua New Guinea, LLDAT is serving to establish a working model for micro-credit activities in the Papua New Guinea environment. As such it is paving the way for future expansion of micro-credit work in the country. This represents an important step in bringing a recognised approach to sustainable reduction of hard-core poverty at the grass roots level to Papua New Guinea, where the need for such development remains high. Many of Papua New Guinea's pressing social and economic

\section{Figure 1 LLDAT: Physical progress, 1994-96}

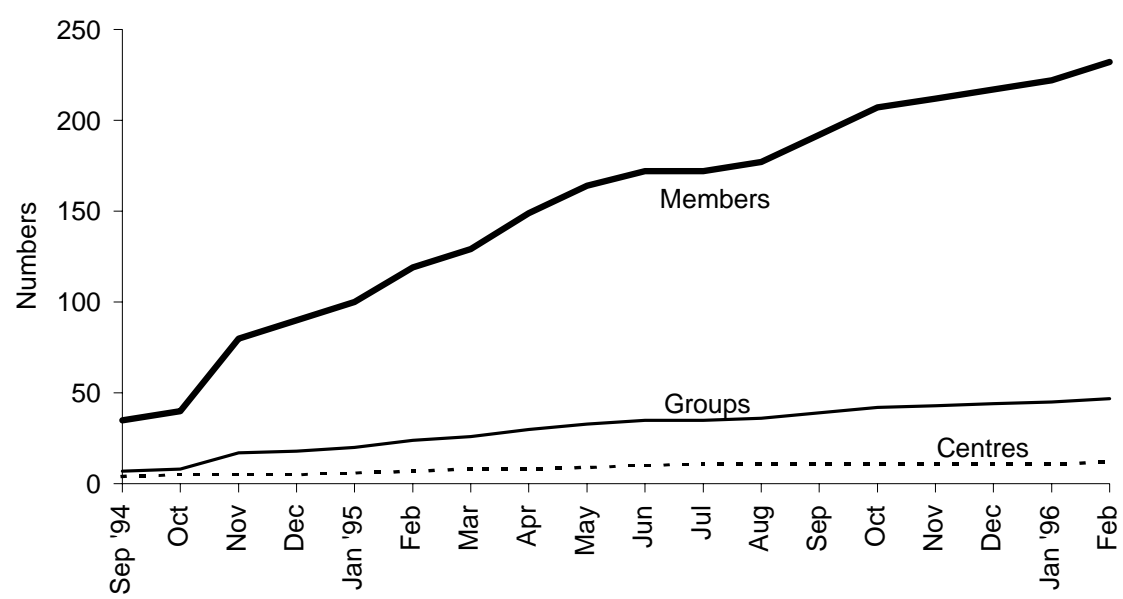

Source: LLDAT, 1996. Micro Credit and Savings Project Progress Report at the End of February 1996, LLDAT Project Office, Goroka. 


\section{Table 2 LLDAT: financial progress, 1994-96}

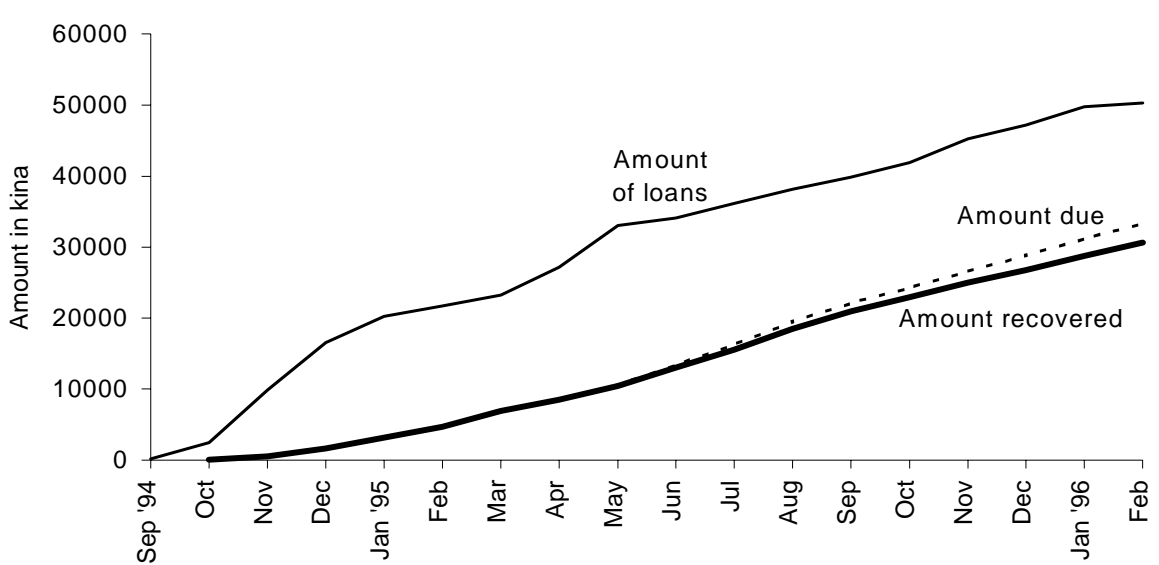

Source: LLDAT, 1996. Micro Credit and Savings Project Progress Report at the End of February 1996, LLDAT Project Office, Goroka.

problems have not been addressed through government and aid-funded programs to date. Many have tended to be large-scale and top-down in approach. Specifically, the need for credit and savings facilities among the poor (especially poor rural women) has not been addressed through these programs. In developing a suitable micro-credit model for Papua New Guinea, LLDAT represents a vital step towards achieving sustainable poverty reduction in Papua New Guinea.

\section{Table 3 LLDAT: deposits mobilisation, 1994-96}

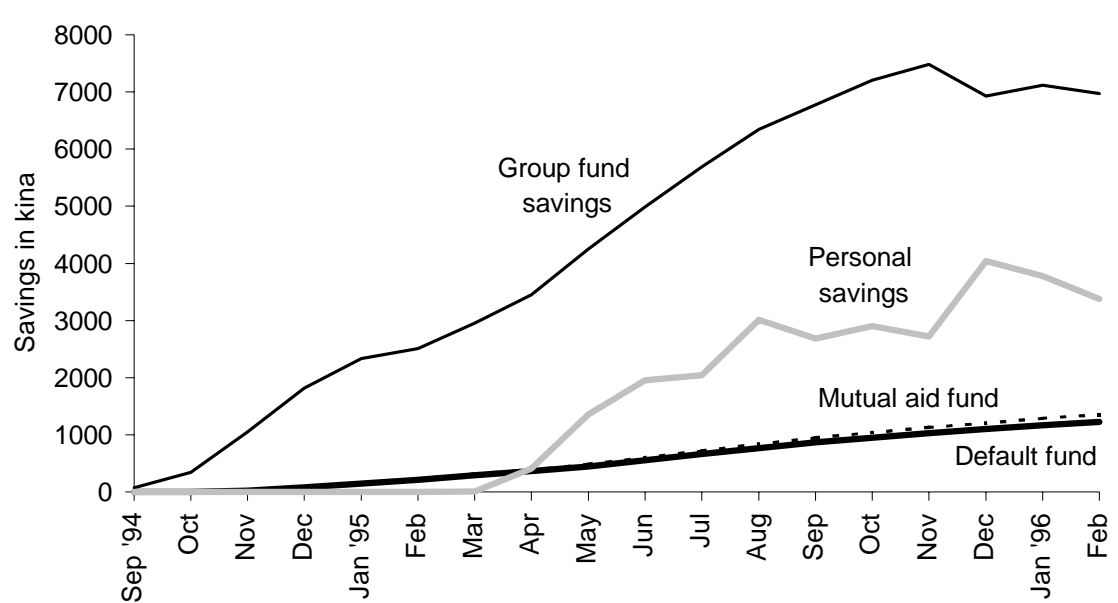

Source: LLDAT, 1996. Micro Credit and Savings Project Progress Report at the End of February 1996, LLDAT Project Office, Goroka. 


\section{Weaknesses and criticisms of the scheme}

The LLDAT scheme has experienced several major problems during its period of operation. It has also been the butt of numerous criticisms. In reality this is only to be expected in a country where the concept is relatively new, conditions are difficult, and resources are very limited.

Erosion in the loan recovery rate is a major concern. Although LLDAT has consistently managed to maintain a much higher repayment rate than other microcredit schemes in Papua New Guinea, the current rate of 92 per cent falls well below the Grameen minimum of 97 per cent. LLDAT staff believe that the decline in the repayment rate is due to a combination of factors, including erosion in Centre discipline, increased expenses for loanees related to the December festive season, tribal fighting, and increasing misuse of loan money and wilful defaulters (LLDAT recently took 32 wilful defaulters to court and won the case; this was a costly and time-consuming exercise, but was considered necessary to discourage future defaulters). Staff are making major efforts to reduce these problems through a number of actions, including closer monitoring, stricter discipline and legal actions. It is hoped that with these efforts, the loan recovery rate will gradually increase. However, improvement in the loan recovery rate will be a slow process, and achieving financial sustainability will take considerably longer than expected.

Another major criticism of the scheme is that it is highly resource intensive for relatively small-scale and localised benefit. On the surface this is certainly how it appears; basic calculations show that with over US\$600,000 (approximately K770,000) of inputs to date, totals are approximately K2500 per person assisted, or K10 in overheads for every K1 lent. However with further analysis these figures appear more acceptable. These ratios will decrease as the scheme expands (given that inputs to date have largely been establishment costs which will serve for the duration of the scheme), and as it moves towards longterm sustainability. Furthermore in terms of developing a suitable and sustainable model for micro-credit activities in Papua New Guinea, the LLDAT scheme represents an important investment; as such it will feed lessons into (and hopefully decrease costs for) any future micro-credit schemes in the country.

Other problems experienced by the scheme include the following. Staff salaries are low (LLDAT staff are paid approximately half the salary of tellers in commercial banks), which makes it difficult to attract and keep good staff. Jealousy, the spread of adverse rumours and lack of support (particularly from husbands) have disrupted the activities of some groups, and staff are currently working to redress these problems (for example, by strengthening motivational work, including men in information sessions, openly dispelling rumours and working to broaden the level of community support). Furthermore the scheme has been criticised for being too cultish, and too narrow in its focus. These criticisms and problems are common to the Grameen approach, and reinforce the fact that the Grameen Bank Approach is not the only solution to poverty (the Grameen Bank itself stresses this). It is important to recognise that the LLDAT scheme is not suitable for all people in the target group.

\section{Issues impacting on the scheme}

As with all Grameen Bank replications, individual countries present the model with a set of benefits, constraints and issues unique to that particular environment. The following section looks briefly at the issues particular to Papua 
New Guinea, and the impacts (both positive and negative) that they have on the project.

\section{Supportive factors in the PNG environment}

Papua New Guinea has only a few characteristics which are particularly supportive of a successful Grameen Bank replication.

- Levels of need and enthusiasm for this type of project are high.

- As small-scale rural credit schemes for women have operated in some parts of the country before (for example the Wok Meri movement) a proportion of the population in some areas is familiar with the concept.

- As the majority of the population are Christian, religion does not present a major barrier to the participation of women in income-generating activities (this has been a major obstacle for Grameen Bank projects in Islamic cultures).

- The availability of land in Papua New Guinea provides a broad range of options for women wishing to start income-generating activities, for example agricultural activities (this is much more limited in countries where the majority of the poor population are landless).

\section{Negative factors in the PNG environment}

Papua New Guinea is a difficult environment for the operation of a Grameen Bank replication; the number of difficulties faced by the LLDAT scheme far exceeds the number of supporting factors.

The scattered population of Papua New Guinea, rugged terrain and poorlydeveloped infrastructure present major constraints to the operation of the LLDAT scheme. Transport difficulties constrain the movement of staff, and hence the remotest villages (which often house the most needy people) cannot be reached by the project. The rugged terrain and law and order situation mean that bicycles and motorbikes (which are commonly used in Bangladesh and other Grameen Bank replications) are not viable forms of transport for LLDAT staff, and cars are well beyond the resources of the project. Hence public transport is the only solution. This restricts the project to the more accessible communities.

Transport constraints also restrain the micro-enterprises that are established as a result of LLDAT loans. In the absence of good transport networks, small businesses can only exist in small enclaves and mostly near urban areas. Market 'crowding' is a major problem, and competition can become intense, particularly in small and localised markets. Rural women in Papua New Guinea have not traditionally engaged in a diverse range of income-generating activities (as they have in densely populated countries such as Bangladesh), and they tend to be reluctant to try new things. Diversification of skills may be necessary for the success of LLDAT once the project expands.

The law and order situation in Papua New Guinea presents a major obstacle to the implementation of the LLDAT scheme. Female (and to a lesser extent male) Trust Assistants frequently face risky situations (and a very real fear of theft and rape) when travelling out to villages in the course of their work, particularly when carrying money. Loanees face the same issues in the course of obtaining loans and setting up and running small enterprises. Fortunately there have been no bad incidents related to the project to date, probably due largely to the high level of community support for the project. Other forms of violence which affect the project include domestic violence and tribal warfare (tribal fights have already disrupted the project in several areas). Furthermore, compared to the Eastern Highlands Province, the law and order 
situation in some of the other provinces is worse. This is expected to be a major issue in the expansion of the project.

Social and cultural issues present severe (but not insurmountable) constraints to the scheme.

- Wantoks can and do pressure LLDAT staff and loanees to give away their loan or repayment money; for this reason spending of loan money is supervised, and staff do not work in their home areas.

- Language barriers are often a problem, particularly as staff do not work in their home areas.

- To avoid domestic conflict with men, women need to be particularly careful that their project activities do not interfere with their normal duties. Gaining the support of men for the scheme is essential.

- A hand-out mentality is common in many villages (due to distribution of money by politicians and the old concept of 'cargo cult'). The concept of self-help through loans is often treated with great suspicion, and needs to be taught slowly and carefully.

- As a generalisation, the 'Pacific Way' means that Papua New Guineans generally have a slow and easy attitude to work above the subsistence level (which affects both staff and loanees). This is very different to the ethic of hard work which exists in many countries in Asia.

- Because poverty is not as desperate in Papua New Guinea as in Bangladesh, it is somewhat harder to be strict about enforcing rules and conditions of the LLDAT scheme. This may be a contributing factor to the erosion in the loan repayment rate.

\section{Adapting to the Papua New Guinea environment}

Despite the numerous constraints and limitations presented to the scheme by the Papua New Guinea environment, LLDAT is making good progress in adapting the Grameen Bank model.

Some possible future adaptations which may improve the performance of the project include

- establishing links with conflict resolution training and support facilities, to decrease the impact of violence and tribal fights on the project

- establishing links with training in business and small enterprise skills (for example, BEST), to enhance performance once enterprises expand (and encourage graduation from the scheme to commercial banking services), and to encourage skills diversification and reduce the likelihood of market crowding

- improving conditions for staff (salaries in particular) to improve work performance. Further training for both new and existing staff would also be beneficial.

\section{Conclusion}

The LLDAT Micro-Credit and Savings Scheme has been successful in a number of ways. There is a high level of enthusiasm and broad community support for the scheme in the project area, and there have been significant advances in savings and progression to second-round loans. The scheme has consistently maintained higher repayment rates than other similar schemes in Papua New Guinea, and some progress is being made (albeit slowly) towards financial sustainability. Most importantly, the scheme has already made a number of adaptations to the PNG environment, and is working towards establishing a suitable and sustainable model for further microcredit activities in the country.

The project has experienced significant problems, including a gradual erosion in the loan repayment rate (and hence slow progress towards sustainability), a number 
of serious defaults, and a slow rate of project expansion. Furthermore the scheme has proven to be highly resource intensive during its initial period of operation.

Although for the most part the project has managed to adapt successfully to these and other problems, there remain numerous difficult issues. It is expected that further adaptations of the Grameen model will be required throughout the life of the project to ensure its success.

Micro-credit and the Grameen approach do not present the only answer to Papua New Guinea's development problems. Micro-credit activities are resource intensive, slow to develop, and reach relatively small numbers of people, at least during the early years of operation. Papua New Guinea's social and economic problems are deeply rooted, and need to be addressed at all levels. However, micro-credit certainly has a role in Papua New Guinea, where the need for sustainable reduction of hardcore poverty at the grass roots level remains high. Micro-credit reaches out to the underprivileged population of rural women, a group largely neglected by other development programs. It meets an unmet demand for credit and savings facilities amongst that population, and provides access to a form of self-help through which their lifestyles can be improved. As such it represents an important investment in the future of Papua New Guinea's poor rural women and their families.

\section{Appendix 1}

\section{Detailed operational features of the LLDAT Micro-Credit and Savings Scheme}

\section{Structure of the Trust and the Project}

In order of overseeing, the operational structure of the scheme is as follows: Board of Trustees (National level), Project Office (Provincial level, currently only EHP), Branch (District level, currently only Goroka), Centre (Village level), Group (within village level). Each Centre consists of six Groups from a particular area, and each Group comprises five like-minded women (often from the same village). The Project Office manages the project, while the Branch runs the day-to-day business of the scheme in that Province (these two offices are currently combined).

\section{Preparatory work}

Extensive preparatory work is required before the project commences. This work begins with the site selection process, which involves visits by a Trust Assistant (TA) to a particular locality. Information is collected on the suitability of the area for the project, and the TA works to develop rapport with local people and leaders. Once an area is chosen as a project site, TAs return to conduct motivational work (to encourage people to participate and gain support), to ensure people are fully informed, and to dispel any rumours or problems. The preparatory stage concludes with a Projection Meeting - a public meeting held to formally introduce the scheme.

Gaining the support of village leaders is a crucial part of preparatory work, as leaders are often the people who are relied upon to motivate members of the project and to keep them in line. The support of 
men is also essential; the male-dominated nature of Papua New Guinea society, combined with high levels of domestic violence, means that unsupportive men can cause major difficulties for the project. Efforts are made to include men in the preparatory phases of the project.

\section{Group formation}

Loanee groups consist of five like-minded underprivileged women (not relatives) who come together voluntarily. Groups are the foundation of the operational structure, as the project depends on group support and group pressure for its lending and savings operations. Groups elect a Group Leader and Secretary, and these positions are rotated on a yearly basis.

Interested potential members of a Group undergo 'means testing' (via interview) in order to ensure that they belong to the target group. Means testing takes income, housing and assets into account (overall criteria is a per capita household income of less than K15 per month). Once all members have passed the means test, a 'Group Acceptance' meeting is held to introduce them to the Centre.

\section{Training}

Training is rigorous at all levels of the project. Staff undergo extensive training prior to taking up positions as Trust Assistants. Current staff were trained in the Grameen Bank approach (and replications) in Bangladesh and the Philippines prior to commencement of the project. Staff recruited at a later date will probably train at the Project Office in Goroka, as funds for overseas training are now limited.

Prior to undertaking loans, Groups which have been accepted undergo a seven-day 'Compulsory Group Training' period, during which they learn Grameen philosophy and all aspects and requirements of the project. This training is conducted by Trust Assistants. At the end of the training the Group must pass a 'Group Recognition Test', which then allows them to proceed to taking loans.

\section{Loan procedures}

Loan proposals are discussed within Groups and Centres before they are submitted to the project Branch for processing. To be eligible for a loan, a project must be viable, legal, of benefit to the family, involve skills the loanee already has, and preferably be quick to generate some income (at least for initial loans). Project loans are the only available loans to date; other types of loans (such as housing loans) have not been set up as yet.

Loan amounts depend on assessment of the requirements of the project and the loanee's ability to repay regularly. Maximum limits of each loan cycle are: first loan cycle K300, second loan cycle K600, third loan cycle K800. Loans are to be repaid over one year and the flat interest rate is 15 per cent (slightly higher than commercial rates, which works to ensure financial sustainability of the project in the long run). Loan instalments are paid at weekly meetings (in the village Centres), and include interest payments. Advance repayments are not accepted, as they have been found to encourage misuse of loans and dominance of some members in the scheme.

Loans are not disbursed to all Group members at once, but are staggered so that regular repayment habits must be demonstrated before all Group members receive their loans. Loans are disbursed in cash at the Branch Office, and all Group members must be present for one member to receive a loan (this is partly to encourage Group responsibility and partly for security reasons). Loan money must be utilised on the project within one week of release of the 
loan. This is monitored by Group and Centre leaders and project staff.

Subsequent loans are only received if the previous loan has been repaid fully and regularly, financial discipline has been displayed, centre meetings have been attended regularly, and projects have proceeded satisfactorily.

\section{Projects}

Loanees select their own projects for utilisation of loans, using skills and experience they already have (TAs are available for advice if required). Loanees are encouraged to have a main project, which may take a little longer to start producing income (e.g. raising chickens/pigs, gardens, selling second-hand clothing, small trade stores, sewing, nursery) as well as a quick-earning supplementary project (e.g. baking, peanut or betel nut selling) to enable them to begin repaying loans immediately. Loanees are encouraged to build on their existing skills as they proceed through the scheme.

\section{Monitoring and Centre procedures}

Centres are administered by the Centre Chief and Deputy Chief (elected positions which rotate on a yearly basis), who organise weekly meetings and run all other aspects of the Centre. Attendance at meetings is compulsory for all loanees. As well as issues directly relating to the credit and savings aspects of the project, Centre meetings can also be used to discuss more general community development issues (including health issues, organising training programs, organising community events, and so on).

Trust Assistants attend weekly Centre meetings. This allows them to monitor loans very closely, including checking loan repayments, utilisation of loan money, and progress of projects. This approach also allows TAs to deal with any problems that come up on a regular basis. TAs receive the loan and savings instalments, and transport them to the Branch Office. From the Branch Office funds are deposited into an LLDAT account at the local commercial bank.

\section{Savings}

Loanees make weekly deposits into three compulsory savings funds.

Group Fund. Each Group member contributes K1 per week into the Group Fund. The principle of this fund is that small regular deposits can add up to a considerable amount through a Group. When the Group Fund reaches a minimum of K100, Group members can start borrowing from it for project expansions and emergencies.

Default Fund. This is a Centre-based fund which is set up to help loanees with repayment problems (and to ensure that responsibility for wilful defaulters does not fall entirely on a Group or Centre). All loanees contribute $\mathrm{K} 0.20$ to this fund each week. The Default Fund constitutes an additional source of savings for members if it isn't used to cover defaulted loans.

Mutual Aid Fund. This is also a Centrebased fund which is set up to provide relief to a member's family in the event of the death of a member. Deposits to this fund are 5 per cent of the total loan amount (divided into weekly instalments). In the event of a death, the amount received by the family is set according to the loanee's position in the loan cycle (and the loan is written off).

Loanees also have the option of starting a Personal Savings Scheme. Personal savings earn interest at the commercial rate through LLDAT, and conditions of withdrawals and deposits are relatively unrestricted. 


\section{References}

Papua New Guinea, Department of Religion, Home Affairs and Youth, 1995a. Papua New Guinea Country Report-United Nations Fourth World Conference on Women, Beijing, China, Department of Religion, Home Affairs and Youth, Port Moresby.

1995b. Papua New Guinea Platform for Action-A Decade of Action For Women Towards National Unity and Sustainability, Department of Religion, Home Affairs and Youth, Port Moresby.

Fernando, N., 1991. Informal Finance in a Semi-Subsistence Economy-A Case Study of Papua New Guinea, National Research Institute, Port Moresby.

Grameen Trust, 1995. Grameen Dialogue, October, Newsletter Published by the Grameen Trust, Bangladesh.

Kalap, M. and Tambagle, C., 1996. Reports on Simbu Women's Credit Project, Department of Provincial and Local Level Government, Simbu Province.

LLDAT, 1996. Micro Credit and Savings Project Progress Report at the End of February 1996, LLDAT Project Office, Goroka.

New Zealand, Ministry of Foreign Affairs and Trade, 1993. Papua New Guinea Women's Credit Project: an appraisal of a Papua New Guinea Government Proposal, draft report, New Zealand Ministry of Foreign Affairs and Trade, New Zealand.

UNDP, 1993. Project Document: Papua New Guinea Micro-Credit and Savings Project UNDP, United Nations Development Programme, Port Moresby, Papua New Guinea. 